\title{
Product Standards and Firms’ Export Decisions
}

\section{Ana M. Fernandes, Esteban Ferro, and John S. Wilson}

\begin{abstract}
Two novel datasets are used to estimate the effect of product standards on firms' export decisions. The first covers all exporting firms in 42 developing countries. The second covers pesticide standards for 243 agricultural and food products in 80 importing countries over 2006-2012. The analysis shows that product standards affect significantly foreign market access. An increase in the stringency of standards in the destination country, relative to the exporting country, lowers firms' probability of exporting, deters exporters from entering new markets, and fosters exit from existing markets. Smaller exporters are more affected in their market entry and exit decisions by the relative stringency of destination standards than larger exporters. Networks of other exporters from the same country can help overcome the negative effects of the relative stringency of destination standards on exporter entry and exit.
\end{abstract}

JEL classification: F14, Q17, O13, L15

Keywords: Exporter dynamics, Entry, Exit, Intensive margin, Extensive margin, Non-tariff measures, Product standards

While there is evidence that the substantial decline in tariffs over recent decades has fostered growth in world trade, the consequences of the growing use of nontariff measures (NTMs), generally in the form of import regulations, by both developed and developing countries are less well understood. ${ }^{1}$ There are legitimate reasons for countries to impose NTMs-for example, health and safety reasons in the case of food standards__ but some anecdotal evidence suggests that NTMs restrict market access particularly

Ana M. Fernandes (corresponding author) is a senior economist in the Trade and Integration Unit in the Development Research Group at the World Bank, and her email is afernandes@worldbank.org. Esteban Ferro is an economic consultant in the Trade and Integration Unit in the Development Research Group at the World Bank, and his email is eferro@worldbank.org. John S. Wilson is a fellow at The Center for Global Enterprise, and his email is jwilson@thecge.net. The authors are grateful to Jose-Daniel Reyes, Michele Imbruno, as well as participants at the 2014 European Trade Study Group conference, the 2016 CSAE conference, and the World Bank DECTI brown bag for comments. Research for this paper has been supported in part by the World Bank's Multidonor Trust Fund for Trade and Development and through the Strategic Research Partnership on Economic Development. We also acknowledge the generous financial support from the World Bank research support budget and the Knowledge for Change Program (KCP), a trust funded partnership in support of research and data collection on poverty reduction and sustainable development housed in the office of the Chief Economist of the World Bank. The findings expressed in this paper are those of the authors and do not necessarily represent the views of the World Bank. A supplementary online appendix to this article is available at The World Bank Economic Review website.

1 NTMs are a key topic of negotiation under new trade agreements such as the ongoing Transatlantic Trade and Investment Partnership negotiations between the United States (US) and European Union (EU). As tariffs in the EU and US are low, any substantial impact of such agreement on trade flows for signatories and third markets will be driven by changes in NTMs. 
for smaller exporters in developing countries. More importantly, the effects of NTMs on trade are difficult to assess empirically due to the breadth of regulations covered as well as their technical complexity.

In this paper, we provide rigorous econometric evidence on the effect of product standards on trade using firm-level data. We estimate the effect of pesticide residue limits standards—a type of NTM- set by exporting and importing countries on agricultural and food products on firms' decisions to export, enter, or exit a product-destination market as well as their effect on export values, quantities, and unit prices. To do so, we combine two novel datasets, one covering all exporting firms in 42 developing countries and one covering pesticide standards for 243 agricultural products in 80 importing countries over the 2006-2012 period. Agricultural and food products are an important component of the export portfolio of the developing countries in our sample, accounting on average for 20 percent of their total exports, and play a critical role for the development of poor rural areas in most developing countries. ${ }^{2}$

The Sanitary and Phyto-Sanitary (SPS) standards considered in this paper are Maximum Residue Levels (MRLs), which determine the maximum levels of residues for pesticides legally permitted on unprocessed food. ${ }^{3}$ MRLs are mandatory regulations that condition market access in order to ensure that domesticallyproduced and imported unprocessed food is safe to eat. ${ }^{4}$ Countries are quite heterogeneous in the products and pesticides they regulate and in the MRL they allow for a given product-pesticide pair. $^{5}$ In order to meet required MRLs, producers need to avoid using certain pesticides and determine the correct preharvest intervals, which results in the need to use more expensive inputs and more specialized human capital. Noncompliance with an MRL can lead exporters to lose the full shipment value and be subject to additional monitoring and testing until multiple shipments successfully cross the border. ${ }^{6}$

Our main findings are as follows. First, an increase in the relative stringency of standards in the destination country compared to the exporting country significantly lowers firms' probability of exporting, deters exporting firms from entering new markets, and fosters exit from existing markets. Firm exports at the intensive margin are not significantly affected by the relative stringency of standards. Second, smaller exporters are more negatively affected in their market entry and exit decisions by the relative stringency of standards than larger exporters. Network effects__ captured by the presence of firms from the same country exporting the same product to a given destination_—reduces the negative effect of the relative stringency of destination country standards on firms' decisions to enter new destination markets. Also, firms are less likely to exit a destination market due to changes in the relative stringency of standards when the product affected by the changes accounts for a high share of the firm's export portfolio.

The contribution of our study is threefold. First, ours is the first study that examines the relationship between explicit measures of product standards and firms' export decisions for a large set of developing

2 The average masks country heterogeneity in the share that agricultural and food products represent in total exports, ranging from 50-60 percent for Kenya, Nicaragua, and Uganda to five percent or less for Bangladesh, Botswana, Cambodia, and Mexico.

3 Residues from pesticides are tiny traces of pesticide that sometimes remain on treated crops.

4 Once pesticides are demonstrated to be safe for consumers, MRLs are set by independent scientists based on rigorous evaluation of each pesticide. MRLs act as an indicator of the correct use of pesticides and ensure compliance with legal requirements for low residues on unprocessed food.

5 The Agreement on the Application of Sanitary and Phyto-Sanitary Measures approved by World Trade Organization (WTO) members in the 1990s embodies the principle that multilateral trade rules allow countries to adopt measures to protect human, animal, or plant life or health, provided such measures do not discriminate or are not used as disguised protectionism. That Agreement sets out the basic rules for ensuring that each country's food safety and animal and plant health laws and regulations are transparent, scientifically defensible, and fair.

6 Noncompliant exporters whose shipments are rejected at the border may also have to pay the cost of shipment along with storage fees overseas while the complaint is processed, a fee to dispose of the product or re-export it, and potentially a violation fee. At the extreme, MRL violations lead to complete import bans for specific origin countries. For example, in 2002, imports of frozen spinach from China were banned by Japan due to the finding of a pesticide (Chlorpyrifos) in excess of the allowable MRL. 
countries. Second, in contrast to most previous studies, which rely on a count of standards, our use of MRLs for pesticides allows us to construct indexes that measure the stringency of the standards on a continuous scale. Third, our study focuses on differences in the stringency of standards in the importing/destination country versus the exporting/origin country. Considering the relative stringency of standards in the destination country with respect to that in the exporting country adds variability to our standards measures and thus enables us to include in all our econometric specifications a very stringent set of fixed effects at the exporting country-firm-HS six-digit product-destination level, which imply that our main effects are estimated based on within variation in a panel setting. The fact that our specifications control also for unobserved time-varying exporting country and time-varying destination country heterogeneity via fixed effects and consider the effect of the lagged index of relative stringency of standards mitigates any potential biases caused by omitted variables or endogeneity.

Overall, our findings demonstrate negative average effects of the relative stringency of SPS standards in the destination country compared to the exporting country on the extensive margin of firm exports, in terms of participation, entry, and exit. But our findings also show that, beyond average effects, there is important heterogeneity across exporting firms. Thus, our findings are consistent with the idea that firms face not only a fixed cost to export but also additional costs to meet foreign standards in each market. Only those firms that are productive enough_— size being a proxy for productivity_— are able to cover those costs and enter new foreign markets.

From a policy point of view, SPS standards differ across countries, and this heterogeneity is likely to remain in place since full global harmonization of such standards is not likely. At the multilateral level, the WTO SPS agreement has not been able to bring discipline for countries to adhere to the Codex Alimentarius standards (henceforth referred to as Codex). At the bilateral level, SPS standards have only recently begun to be discussed in the context of deep trade agreements (which include provisions on technical barriers to trade) but with limited progress achieved to date. For developing countries seeking to support agricultural exporters in their entry and survival in markets with more stringent SPS standards, our work suggests that governments need to optimize the regulatory framework and provide the proper infrastructure that would allow exporters to minimize the costs to meet foreign and local standards.

The remainder of the paper proceeds as follows. Section 1 reviews the literature on product standards, and section 2 discusses the conceptual framework. Section 3 describes the data while section 4 presents the empirical framework. Section 5 discusses the main results. Section 6 focuses on endogeneity, alternative standards indexes, and the role of quality. Section 7 concludes.

\section{Literature Review}

SPS and Technical Barriers to Trade (TBT) — two major types of NTMs_are regulatory measures meant to protect domestic human health, animal and plant health, and the environment. While these measures may legitimately address market failures and spillovers, they may also create trade frictions and serve protectionist motives. Higher-income countries tend to have higher degrees of societal awareness and concerns about the standards of the food they consume and, thus, tend to impose stricter standards, particularly SPS standards. ${ }^{7}$

The effect of these two major types of NTMs on trade is ambiguous, particularly for developing countries. On the one hand, standards can act as trade facilitators by signaling that products allowed into the market are safe to the consumer, which is valuable under asymmetric information. The quality improvements required to comply with such standards enhance consumers' demand for imports, which, in turn, creates incentives for developing countries' exporters to modernize their supply chain structure

7 The literature shows that wealthier households typically consume goods of higher quality (e.g., Bils and Klenow 2001, Hallack 2006, Broda and Romalis 2009). Ferro et al. (2015) show a direct positive relationship between income per capita and the stringency of SPS standards. 
(e.g., investing in quality assurance), enabling them to improve competitiveness while also strengthening domestic standards. Maertens and Swinnen (2009) show that foreign standards acted as a catalyst for production upgrading in Senegal. On the other hand, standards can increase the costs of exporting. The costs of complying with stringent standards include fixed costs related to upgrading production systems, acquiring special types of processing and storage equipment, implementing quality control procedures, and obtaining certifications, but also variable costs linked to delays and inspection procedures. For developing countries' firms, these costs can undermine the competitiveness of their exports. ${ }^{8}$ Survey evidence suggests that fixed costs of compliance with product standards are important, although recurring costs of compliance tend to be lower. ${ }^{9}$

In the context of recent trade models with heterogeneous firms along the lines of Melitz (2003), conforming to regulatory standards in a destination market constitutes a fixed-entry cost into that market but may also be part of the variable trade costs incurred every time the firm exports to that market, for example, if more costly inputs in particular more expensive pesticides) need to be used to comply with the standards. The models of Chaney (2008) and Bernard et al. (2011) generate predictions about the effects of destination-specific or product-destination-specific fixed trade costs as well as destination-specific variable trade costs on the extensive and the intensive margins of firm exports. They show that variable trade costs affect both margins of firm exports. When variable costs are lower, each existing exporting firm exports more, and more firms enter the export market (as the threshold productivity level above which firms have positive profits from exporting decreases). ${ }^{10}$ Fixed-trade costs affect the extensive margin but not the intensive margin (because existing exporters already paid those costs). In a model with a single firm making export decisions, Chen et al. (2010) allow compliance with standards to impose additional production costs on firms but also to have a positive effect on demand (by affecting consumers' willingness to pay). The net effect of standards on a firm's choice of optimal export scale and scope depends on the strength of the standards-induced cost increase versus the standards-induced demand increase. Xiong and Beghin (2010) attempt to disentangle the demand-enhancing and trade-cost effects of the stringency of SPS standards adopted by OECD countries for imports of plant products. They show that more stringent SPS standards in the importing country often jointly enhance import demand for plant products and hinder foreign exporters' supply, particularly for less developed countries.

Although multiple studies analyze the impact of product of standards on aggregate trade flows using a gravity model setting, to our knowledge only three studies examine how product standards affect firms' trade patterns. ${ }^{11}$ Chen et al. (2010) use cross-sectional data from a World Bank survey of firms covering compliance with technical barriers to trade and firm export behavior and show that quality standards and

8 See Henson et al. (2000) on the challenges related to product standards faced by firms in developing countries.

9 Using firm-level data from the World Bank Technical Barriers to Trade Survey for 16 developing countries, Maskus et al. (2005) show that fixed costs represent on average 425,000 US dollars per firm (or 4.7 percent of value added) but the elasticity of firm-variable production costs to standards and technical regulations is only in the 0.06 percent-0.13 percent range. Case study evidence for shrimp exports from Nicaragua shows that fixed costs to comply with quality and safety standards represent less than 3 percent of total annual exports while costs to maintain compliance represent less than 1 percent of that total (Cato et al. 2004).

10 A firm's profitability from exporting varies with the market: it is more profitable to export to markets with high demand, low variable trade costs, and low fixed costs. Only a subset of firms export and that subset varies with the characteristics of the market.

11 Evidence of trade-impeding effects from SPS standards based on a gravity model is provided by Otsuki et al. (2001a, 2001b), Wilson et al. (2003), Disdier et al. (2008), Anders and Caswell (2009), and Tran et al. (2011) while evidence of insignificant effects is provided by Xiong and Beghin (2010). Ferro et al. (2015) show that more restrictive SPS standards are associated with a lower probability of positive agricultural trade flows, but, after controlling for sample selection, standards do not significantly affect the volumes of trade per se. They interpret this finding as indicating that complying with stringent SPS standards increases the fixed costs of exporting, but, once firms enter the market, standards do not significantly impact their level of exports. In addition to studies focusing on mandatory technical regulations-as 
labeling requirements are positively correlated with firms' average export volume and scope (number of destinations and products) while certification procedures are linked to a decline in export scope. A clear limitation of that study is its use of subjective responses by firms of whether their exports were impacted by different types of standards. Reyes (2011) shows using customs data that the harmonization of EU electronics regulations with international standards led to the entry of new US exporters of electronics products into the EU. Fontagné et al. (2015) examine the impact of SPS concerns raised in the WTO Committee on SPS on French firms' export behavior using customs data. SPS concerns reduce firms' probability of exporting and export value and increase their export prices. The impact is heterogeneous across firms, with the negative impact of SPS concerns being lower for larger firms exporting to multiple destinations. The authors argue that, by identifying SPS measures perceived as trade barriers, their SPS concerns data are preferable to the use of WTO notifications or traditional sources of information on the existence of a regulation. But their data could raise potential reverse causality concerns, as only countries whose exports are depressed by an importing country's SPS are likely to raise a concern at the WTO. Ultimately, they show that their results are robust to alternative econometric treatments of endogeneity (the use of lags of the SPS concerns measure and an instrumental variables strategy). A key advantage of our study relative to the single exporting country studies by Reyes (2012) and Fontagné et al. (2015) is that it relies on data for firms in 42 exporting countries, which will allow us to consider a measure of the relative stringency in MRL standards-the standards index described in section 3-in the exporting country versus the destination country.

\section{Conceptual Discussion}

In our empirical framework, we will test hypotheses related to whether higher stringency of SPS standards in a destination country compared to an exporting country enhances or hampers that exporting country's firms' export participation, entry, and exit decisions and their intensive margin of exports (values, quantities, and unit prices), drawing upon the aforementioned predictions from the literature on heterogeneous firms and trade. Regarding firm entry, relatively more stringent SPS standards in a destination country could deter it for firms from an exporting country with looser standards for two reasons. First, potential new exporters to a market suffer from asymmetry of information relative to domestic firms or incumbent exporters as the collection of information on regulations imposed across foreign markets is costly. Second, firms need to adapt production methods to meet the different standards imposed by each destination and complying with more stringent standards requires larger investments (fixed trade costs) by firms. But consumers in countries with more stringent SPS standards may increase their demand and be willing to pay a "quality premium" for imported products if they know those are safe to consume, incentivizing firms abroad to cover the costs of entering those destination countries. Regarding firm exit, our conjecture is that as the relative stringency of SPS standards increases in a destination country, some firms stop exporting there since they are unable to comply with the strengthening of standards. Regarding the intensive margin, if relatively more stringent standards in a destination market increase firms' variable trade costs, this could reduce firms' export values or quantities and increase unit prices (if higher stringency results in a price premium). But, if higher fixed trade costs ensuing from more stringent standards reduce entry into and foster exit from that destination market (lowering export participation), incumbent firms' export values and quantities could actually increase. Hence, the effect of SPS standards on the intensive margin of firm exports is theoretically ambiguous.

The SPS standards prevalent in the destination country are the binding regulation for an exporting firm, regardless of the exporting country's own standards, because the firm needs to comply with destination

our MRLs are-studies such as Czubala et al. (2009) and Shepherd and Wilson (2013) focus on voluntary technical regulations and show they inhibit trade when they are not internationally harmonized. 
country standards. But it is useful in the context of trade models with heterogeneous firms to consider also the role of the exporting country's own standards, which affect the costs of selling in the home market and the relative costs of exporting. On the one hand, if an exporting country strengthens its standards-for example to harmonize them with those of a richer partner country-the costs for firms to sell in the home market increase as they adjust their production techniques to comply with the more stringent standards. ${ }^{12}$ This increases the minimum productivity threshold for firms to sell profitably in the home market, thus reducing the number of firms selling there. However, the relative cost of exporting decreases if standards in the destination country are unchanged, reducing the minimum productivity required for firms to be able to profitably export, and increasing the number of exporters. Hence, firm export participation and entry are expected to increase with this relative loosening in standards in the destination country compared to the exporting country.

On the other hand, if an exporting country loosens its standards, there is no guarantee that all local firms would benefit from lower production costs because some might choose to continue producing at the higher standard to avoid incurring a sunk cost to adjust production to the new looser standard. ${ }^{13}$ Nevertheless, it is still likely that the minimum productivity threshold for firms to sell profitably in the home market will decrease, resulting in more firms selling there. In this case, the relative cost of exporting increases if standards in the destination country are unchanged, increasing the minimum productivity required for firms to profitably export, and reducing the number of exporters. Hence, export participation and entry are expected to decrease in the face of the looser standards imposed by the exporting country, which lead to an increase in the relative SPS standards of the destination country. ${ }^{14}$

A benchmark to the stringency of standards are Codex standards, a set of international standards for food safety and consumer protection developed by the Food and Agriculture Organization and the World Health Organization. Following the reasoning above, an exporting country's choice of standards that are more or less stringent than Codex could depress its firms' exports and export participation. In our empirical approach, we will address this possibility by estimating specifications with alternative standards indexes that capture deviations from Codex and are defined separately for the destination country and for the exporting country.

The crucial insight from the conceptual discussion above is that, in our empirical framework where a measure of relative standards in the destination country compared to the exporting country will be used, a widening gap can be caused by more stringent destination country standards or by more lenient

12 This discussion draws on the firm heterogeneous trade model proposed by Augier et al. (2015) to study the effects of the harmonization of standards between a developing country and a richer country with stricter standards. They show that the effects on firm profits and competition in the home developing country are complex and ambiguous. Harmonization implies relatively lower costs for developing country firms to export to the richer country, since standards are now similar. But the more stringent standard in the home developing country imposes an extra cost of access for firms from third countries (with looser standards) which may stop exporting there. This in turn may increase the incentive for firms in the richer country to enter the home country market as competition from third countries in that market is reduced. Unfortunately, since our data covers only firms' sales in foreign destination markets (not in the domestic market), we are unable to exploit the predictions for home market competition from Augier et al. (2015).

13 An exporting country that relaxes its MRL standards may allow more of the same pesticides to remain on the food products, but that does not mean that a firm can simply produce with cheaper more toxic pesticides, because those may still be banned. So a looser (higher allowable) MRL may not reduce a firm's production costs, because the firm would need to spend more on pesticides (to the new higher allowable amount).

14 In a richer setting with market failures and bounded rationality, SPS standards could affect firm productivity and profits through channels other than selection and general equilibrium effects. For instance, the imposition of stricter product standards could contribute to overcome market failures due to information asymmetries, making quality claims more credible. They could also help overcome management failures by improving information on best practices and modern technology. 
exporting country standards (or both). ${ }^{15}$ For firms, the effect is observationally equivalent as the relative costs of exporting increase in both cases. Thus, any estimated negative effects of our relative standards index on firms' exports at the extensive or intensive margin are not necessarily evidence of restrictive trade practices by destination countries. Rather, they may result from looser standards imposed by our 42 exporting (developing) countries.

Ultimately, the reality of firms' export decisions based on destination country standards may be more nuanced than the discussion above suggests. Destination markets such as the EU and Japan, where consumers are concerned about product safety, are willing to pay a premium for products that comply with their more stringent standards. Some firms in developing countries will be willing to incur in the additional costs to meet those standards if that means capturing that price premium. Thus, looser standards in the home market will not prevent them from entering destination markets with more stringent standards, as some of those firms might not even sell at home. But the critical issue is that only a few of the firms will be able to incur in those additional costs the larger (and more capital-intensive) ones, whereas smaller firms are unlikely to be able to meet the additional costs to comply with the foreign standards. Trade models with heterogeneous firms such as those by Arkolakis (2010) and Spearot (2014) suggest that trade policies or regulations can affect firms' export decisions differently depending on firms' characteristics. In particular, the impact of product standards on firms' export decisions may depend on firm productivity, hence on a firm's ability to overcome additional costs to enter export markets (proxied in our case by firm size). In that setup, relatively more stringent destination country standards could have a more detrimental impact on small exporters. Additionally, standards could affect firms entering a new product-destination market differently than firms already exporting to that market. In our empirical approach, it will be crucial to account for firm heterogeneity in the effects of standards on the extensive margin of firm exports. Our conjecture is that relatively more stringent standards in the destination market are a bigger obstacle for small firms which are unable to profitably incur in the additional costs to meet the foreign standards.

\section{Data and Variable Description}

Two novel datasets are used to analyze the impact of products standards on trade. The first is a collection of MRL data on agricultural products for 80 importing countries. The second is a compilation of customs data for 42 developing countries. These datasets are combined to create measures of the dissimilarity of regulation between destination and exporting countries and of firm exports at the extensive and intensive margin. The advantages and caveats of the datasets are described in the following sections.

\section{Data on Standards}

The policy variable measures the restrictiveness of mandatory standards based on the MRLs of pesticides allowed for agricultural products in several importing countries. ${ }^{16}$ The source for the data is the

15 A trade barrier resulting purely from a loosening of standards by the exporting country (rather than a strengthening of standards by the destination country) could be obtained in a simple theoretical framework with homogenous products (i.e., no quality premium for products complying with more stringent standards) where firms are assumed to be unable to use production techniques satisfying different levels of standards because differentiating batches of a product without contamination is prohibitively costly. If a country loosens its standards relative to an initial equilibrium with similar standards across countries, its firms will face lower costs to sell in the home market, but firms from other countries (whose standards are unchanged) unable to differentiate their batches are at a cost disadvantage and likely exit that home market. Some firms in the country which loosened its standards could stop exporting (to destination markets with more stringent standards) to focus on the relatively more profitable home market. While theoretically plausible, in supplementary online appendix S3 we show that the assumption that firms are unable to produce a given product to meet different standards is not supported by our data.

16 These standards apply both to domestic production and to imports of the products. 
Homologa database obtained from Agrobase-Logigram, a French company that collects information on initial levels and monthly changes in allowable pesticides for 63 importing countries from each country's relevant ministry and standardizes the information in terms of language, unit, and format for the period 2006-2012. The Homologa dataset reports only the importing countries' list of regulated pesticides. But many countries use a 'deferral policy' for pesticides for which they have not set a specific limit (e.g., the EU default MRL is 0.01 parts per million [ppm] and many countries defer to Codex standards). In fact, many developing countries do not have a list of regulated pesticides but instead directly defer to Codex standards. For the empirical analysis, we use all the information available for each importing country, including own regulated MRLs, deferral policies, and default MRLs. This information is available for 80 countries. Figure S1.1 in the supplementary online appendix provides the list of countries for which we have data on pesticide standards and indicates whether each country has its own set of regulations and what is each country's deferral policy.

Using Agrobase-Logigram's Homologa data we matched 243 agricultural products to their corresponding harmonized system (HS) codes at the six-digit level of disaggregation. ${ }^{17}$ The agricultural products belong to HS chapters 06-24 with the exception of HS chapters 15-16 (oils and edible preparations of meat and fish). ${ }^{18}$ Table S1.2 in the supplementary online appendix, for each importing country, the number of HS six-digit products whose MRLs are specifically regulated and the number of HS six-digit products regulated including deferral and default policies. In total across all importing countries, the number of products regulated range from 214 in 2006 to 241 in 2012. Product coverage is heterogeneous across countries (e.g., in 2012 pesticide limits were set by Brazil on 73 products and by the EU on 136 products). But each country's product coverage is fairly constant across time. ${ }^{19}$ The US, Canada, Australia, Japan, and the EU (if default MRLs are accounted for) are the countries with widest product coverage and with largest breadth of MRL regulations regarding the number of pesticides, shown in supplementary online appendix table S1.3. In total, the importing countries in our sample regulated 863 pesticides in 2006 and 992 in 2012. Japan, the Republic of Korea, Switzerland, and the EU have the most extensive coverage of specific pesticides.

There are three challenges when working with MRL data. First, two dimensions need to be considered: the number of MRL regulations per product and how stringent those MRL regulations are. Second, the heterogeneity of pesticides regulated across products and countries makes cross-country comparisons difficult. For example, since the 16 pesticides regulated for oranges in the Russian Federation might not be included among the 102 pesticides regulated for oranges in Brazil in 2011, how can the two countries pesticide standards on oranges be compared? Averaging MRLs across pesticides for each country-product pair would generate a misleading measure. Pesticides differ in their degree of toxicity, and highly toxic pesticides tend to have more stringent (lower) MRLs than less toxic pesticides in all countries. The group of pesticides a country chooses to regulate for a specific product will determine if the country's average MRL is high or low without providing any information on the actual stringency of those regulations relative to other countries. Consequently, it is imperative to normalize MRLs at the product-pesticide level by a common denominator, given by the difference between the maximum and the minimum MRL across all countries, to account for the degree of toxicity. Third, it is not clear how to address the missing values that originate from a pesticide being regulated in one country but not the other. We cannot replace

17 While Homologa's product coverage is greater than 243 products, we were unable to match all products directly to an HS code.

18 We omit HS chapters 15-16 from the analysis since they include animal products for which importing countries also regulate veterinary drug MRLs, which are not covered by our pesticide MRLs dataset.

19 Only 35 products have pesticide limits regulated by all countries in the sample, among which we find: potatoes, tomatoes, peas, beans, apples, oranges, wheat, maize, sorghum, and ground nuts. 
these missing values with zeros because an MRL set to zero is equivalent to banning that pesticide entirely. We choose to fill in these missing values with the least stringent regulation-the maximum MRL-across all importing countries for each product-pesticide pair. This assumes that, for the purpose of our standards index, a country which does not set an MRL for a product-pesticide pair (directly or through its deferral policy) is in essence deferred to the least restrictive MRL across all countries. But we will consider in section 6 an alternative strategy where the deferral policy for missing MRLs will be the Codex MRL for each product-pesticide pair, similar to the approach taken by Li and Beghin (2012).

We use a measure of the relative stringency of pesticide standards, initially proposed by Ferro et al. (2015), which relies on the difference in standards for a product across the exporting country $c$ and the importing/destination country $d$ and is defined as follows:

$$
\text { Rel_standards } s_{c, k, d, t}=\frac{1}{N(a)} \sum_{n(a)=1}^{N(a)} \frac{M R L_{c, k, a, t}-M R L_{d, k, a, t}}{M A X_{k, a, t}-M I N_{k, a, t}}
$$

where $k$ is an HS six-digit product, $a$ is a pesticide, and $t$ is a year. The MRL standard at the countryproduct-pesticide-year level is $\varepsilon_{M} R L_{c, k, a, t}$ for the exporting country and $M R L_{d, k, a, t}$ for the destination country while $M A X_{k, a, t}=\max _{(d \in D)}\left\{M R L_{d, k, a, t}\right\}$ is the maximum pesticide standard across all countries and $M I N_{k, a, t}=\min _{(d \in D)}\left\{M R L_{d, k, a, t}\right\}$ is the minimum pesticide standard across all countries. If a country does not set an MRL for a given product-pesticide pair we replace the missing $M R L_{c, k, a, t}$ or $M R L_{d, k, a, t}$ with the least restrictive standard, $M A X_{k, a, t}$. The standards index varies between -1 and 1 , it equals 0 when both destination country and exporting country share the same MRLs for a product, it equals 1 [ -1$]$ when the destination country has the most stringent [least stringent] MRLs and the exporting country has the least stringent [most stringent] MRLs for a product. ${ }^{20}$ Positive values of the index indicate that the destination country has relatively more stringent standards than the exporting country.

A key advantage of our standards index is that it combines into one measure the number of regulated pesticides and the intensity with which they are set. Another advantage is that, for every product, our index includes all pesticides regulated in the world; this contrasts to the limited set of product-pesticide pairs regulated by Codex standards considered by Li and Beghin (2012). Finally, another advantage is that, through the use of a common denominator capturing the least and most restrictive MRLs across countries for a given product-pesticide, our index accounts for the fact that some pesticides are more toxic than others and thus allows for an adequate comparison of the stringency of MRL standards across countries. More generally, our standards index informs on the dissimilarity-although not in absolute terms-in the stringency of regulatory requirements across the destination country and the exporting country. ${ }^{21}$ As such, it allows us to consider whether the prevalence of relatively more stringent pesticide standards in the destination country imposes additional costs on firms and, thus, potentially limits exporters' market access.

20 If $M R L=M A X=M I N$, for example when only one of the countries regulates a specific product-pesticide pair, the ratio inside the summation equals one. In absolute terms, a higher value of the index indicates more dissimilar standards between the destination and the exporting country.

21 Winchester et al. (2012) examine how the dissimilarity in sanitary, phytosanitary, and conformity requirements (including product requirements such as MRLs for pesticides) across the EU and several of its trading partners affect their bilateral trade but do not consider the stringency of those requirements as we do in our study. Disdier et al. (2015) study the impact of standards harmonization promoted in North-South trade agreements showing a negative impact on South-South trade as well as on North-South trade when the harmonization is on regional (rather than international) standards, but only harmonization is examined, not the stringency of the standards. Drogué and DeMaria (2012) develop an index of (dis)similarity of MRL pesticide standards between importing and exporting countries based on Pearson's correlation coefficient and study its impact on trade, but their product coverage is limited to apples and pears and their index is time-invariant (thus, it cannot be combined with importing country and exporting country fixed effects in a gravity model). They choose to substitute missing MRL information with an MRL of 75, which is the highest MRL found among all regulated pesticides in their sample. 
It is important to highlight that MRL standards are updated frequently, and our estimating strategy takes advantage of this variability over time. Product registrations are withdrawn, new registrations and MRLs are established, and existing MRLs change on a regular basis. Codex MRLs, for example, are updated annually every July. New Zealand typically publishes two MRL amendments per year, and local officials report that they seek to update MRLs every four months. However, changes in MRLs are not always toward more stringent standards, but instead MRLs are frequently increased thus becoming less stringent. On average only 45 percent of MRLs in the dataset are there for the entire panel available for each country, and of those MRLs available for all years, nine percent became more stringent whereas ten percent became less stringent. Analyzing the sources of variation in the standards index in supplementary online appendixes S2 and S3, we show that the main source is variation over time in the intensity of standards. This is an important element to justify the estimating strategy that we will choose for the empirical analysis.

\section{Data on Exporters}

To measure exporter behavior, we use exporter-level customs data for 42 developing countries over the period 2005-2012 obtained from customs agencies (or statistical institutes), collected by the Trade and Integration Unit of the World Bank Research Department as part of their efforts to expand the Exporter Dynamics Database described in Fernandes et al. (2016). Each country's raw dataset covers the universe of exporting firms and provides information on export value and quantity at the firm-product-destinationyear level. Details on the data are provided in the supplementary online appendix. We define the outcome variables capturing firm export decisions focusing exclusively on agricultural and food products (i.e., those belonging to HS chapters 06-24, except HS chapters 15-16) for which pesticide standards are available.

Regarding the intensive margin of trade, we consider as outcome variables the value exported by firm $i$ from country $c$ of product $k$ to destination country $d$ in year $t$ in current US dollars and the quantity exported in kilograms as well as export unit prices obtained as export value divided by export quantity expressed in US dollars per kilogram. ${ }^{22}$

Regarding the extensive margin of trade, in order to define variables capturing firms' decisions to export, enter, or exit a product-destination market, we need to expand (fill in) the initial dataset with only positive exports by adding zeros on some dimensions. If we were to follow the trade gravity equation literature, we would expand the initial dataset to make it a 'square' matrix where every firm in an exporting country would have an observation (a row) for every possible product-destination-year. Such dataset would be computationally impossible to handle and highly cluttered by zeros as most firms export a single product to a single destination. Furthermore, such dataset would imply the firm had the option of exporting any agricultural product to any destination. This is an implausible assumption as other products may be very different from what the firm's capabilities in terms of technology, climate and soil conditions, and other inputs allow it to produce. Our objective is to construct an expanded dataset with observations indicating economically plausible choices for firms without requiring major assumptions. Thus, we choose to expand the initial dataset so that each firm-product-destination has an observation in all of that exporting country's sample years, with a zero export value in years when exports by the firm-product-destination are not occurring. This expanded dataset combined with a stringent set of fixed effects (discussed in section 4) allows us to exploit the panel dimension in the firms' export decisions as pesticide standards change over time. For this expanded dataset, we define:

- a firm export participation dummy equal to 1 in year $t$ if firm $i$ from country $c$ exports a positive value of product $k$ to destination $d$, and equal to 0 otherwise;

22 The customs datasets for Botswana, the Dominican Republic, Guatemala, Macedonia, Pakistan, and El Salvador do not include quantity information; thus, we do not include them in the analysis of the firm-intensive margin of exports. Although export value is available for those six countries, we will use a common estimating sample for export value, quantity, and unit value regressions in the main results. This will allow the estimated impacts on the log of export value to be equal to the sum of the estimated impacts on the log of export quantity and on the log of export unit price. 
- a dummy for firm entry into a product-destination market equal to 1 if firm $i$ exports product $k$ to destination $d$ in year $t$ but did not do so in year $t$-1, and equal to 0 if the firm did not export product $k$ to destination $d$ in year $t-1$ and does not start to do so in year $t ;^{23}$

- a dummy for firm exit from a product-destination market equal to 1 if firm $i$ does not export product $k$ to destination $d$ in year $t$ but did so in year $t-1$ and equal to 0 if the firm exported product $k$ to destination $d$ in year $t-1$ and continues to do so in year $t^{24}$

Supplementary online appendix table S1.4 shows, for each exporting country, the number of firms in our initial dataset. Cambodia and Yemen have the fewest agricultural exporters with less than 50 on average per year whereas Mexico has the most with an average of 3,313 per year. The table also shows, for each exporting country, the number of firms in the expanded dataset, which is similar in every year as by construction each firm in the dataset has the possibility of exporting in every year of the country's sample period. Finally, the table shows the total numbers of observations both in the initial dataset used for the intensive margin specifications as well as in the expanded dataset used for the extensive margin specifications. Supplementary online appendix table S1.5 displays summary statistics for all firms' export decisions used as dependent variables and for the relative standards index.

\section{Empirical Framework}

To examine the effects of pesticide standards imposed by destination countries on developing countries' firms' export decisions, we consider the following specification:

$$
Y_{c, i, k, d, t}=\alpha+\beta_{1} * \operatorname{Rel}_{-} \operatorname{standards}_{c, k, d, t-1}+\gamma * \operatorname{tariff}_{c, k, d, t}+\delta * Z_{c, i, k, d, t}+I_{c, i, k, d}+I_{c, t}+I_{d, t}+\varepsilon_{c, i, k, d, t}
$$

where $c$ is an exporting country, $i$ is a firm, $k$ is a product, $d$ is a destination country, $t$ is a year, the dependent variable $Y$ is either export participation, entry, or exit defined based on the expanded dataset or the log of export value, the log of export quantity, or the log of export unit price defined based on the initial dataset. The variable Rel_standard is the index defined in equation (1), tariff $f$ is the $\log$ of 1 plus the bilateral tariff imposed by the destination country on imports of a specific product from the exporting country, and $\varepsilon$ is an independent and identically distributed (i.i.d.) residual. ${ }^{25}$ The vector $Z$ includes the $\log$ of total annual exports by exporting country-product to control for supply effects and will include also firm characteristics and network-related variables in the specifications described in section 5 .

23 We follow Koenig (2009), Koenig et al. (2010), and Mayneris and Poncet (2015) in allowing for multiple export entries over the sample period for a given firm-product-destination. Multiple entries occur in cases where the firm starts exporting to a product-destination market then stops, and then re-starts exporting to the same product-destination market.

24 Firms exporting to a product-destination market in every year are excluded from the entry analysis but included in the exit and intensive margin analysis (although in the exit analysis they are dropped from the estimating sample given the panel fixed effects used, as they have a zero in the dependent variable in every year). Firms exporting to a productdestination market only in the first year of the sample are included in the exit analysis but not in the entry analysis (as we are unable to determine whether they entered the market in that first year or were already exporting there previously). Firms exporting to a product-destination market only in the last year of the sample are included in the entry analysis but not in the exit analysis.

25 Simple average applied tariffs are used for importing country-exporting country pairs for each product and year available in the WITS-TRAINS (Trade Analysis and Information System) database. We interpolate observations to fill in missing years. For cases where applied tariff data is not available for a given importing country-exporting country-product-year cell, we replace the missing values (i) with Most Favored Nation (MFN) tariffs of the importing country-product-year or preferential tariffs of the importing country-exporting country-product-year if the importing country-exporting country pair has a preferential tariff agreement, or (ii) if those in (i) are not available with the average at the HS 4-digit level (or HS 2-digit level if needed) of the applied tariffs for other HS 6-digit products within the product's HS 4-digit (or HS 2-digit) for that importing country-exporting country-year. 
A first remark on equation (2) concerns the stringent exporting country-firm-product-destination country fixed effects $I_{c, i, k, d}$, designated henceforth as firm-product-destination fixed effects (as each firm belongs to a single exporting country), which are included to account for unobserved heterogeneity at a finely disaggregated level. Those fixed effects account for the fact that certain pathogens and pests are endemic to certain regions, hence the pesticides used are determined by where the crops grow and complying with a given standard can be substantially more costly for certain firms due simply to their location, even if they use a similar production process and produce at a similar scale as firms in another location. Those fixed effects also control for unobserved country-industry factors such as domestic competition that might bias the estimated effect of standards. The coefficient of interest, $\beta_{1}$, is thus identified based on within firmproduct-destination changes in export participation, entry, exit, value, quantity, or unit price as pesticide standards change over time in the destination country relative to the exporting country for that product. The inclusion of the standards index in levels (not in differences) in equation (1) might suggest it explores whether destination countries with relatively more stringent standards exhibit on average higher (lower) exit (entry) of firms in the cross-section, but the firm-product-destination fixed effects imply it is exploring the effect of changes in relative standards over time.

A second remark on equation (2) concerns the inclusion of the standards index with a lag. While it is implausible that an individual firm in one of the 42 developing countries in our sample influences the setting of pesticide MRLs in any destination country, the fact that our standards index measures the relative stringency of standards across destination country and exporting country could raise a reverse causality concern if exporting countries chose their pesticide MRLs based on the capabilities of domestic firms, which determine their export decisions. Our inclusion of the one-year lag of the standards index helps to mitigate this potential endogeneity concern.

A third remark on equation (2) concerns its inclusion of exporting country-year fixed effects, $I_{c, t}$, and destination country-year fixed effects, $I_{d, t}$, as a way to flexibly account for overall demand and supply and general macroeconomic shocks in the countries thus eliminating a potential concern of omitted variable biases. These fixed effects account in particular for the fact that our sample period encompasses the recent Global Financial Crisis. These fixed effects also encompass non-time-varying destination effects such as the sophistication of consumers: more sophisticated consumers will likely demand products with lower pesticide residues, which in turn might drive their governments to impose more stringent standards on food products.

To motivate and support the main empirical results from estimating equation (2) for the extensive margin, we will first briefly present the effects of the relative standards index on firms' export decisions at the extensive margin aggregated to the exporting country-product-destination country-year level, estimated from the equation:

$$
Y_{c, k, d, t}=\alpha+\beta_{2} * \text { Rel_standards } s_{c, k, d, t-1}+\gamma * \operatorname{tariff}_{c, k, d, t}+\delta * X_{c, k, t}+I_{c, k, d}+I_{c, t}+I_{d, t}+\varepsilon_{c, k, d, t}
$$

where Rel_standards and tariffare defined as above and the dependent variable $Y$ is the number of exporters, entrants, or exiters selling product $k$ from country $c$ to destination country $d$ in year $t$. These variables are obtained as sums at the exporting country-product-destination country-year level of, respectively, the firm export, entry, or exit dummy variables defined in section 3. As an alternative to numbers we allow $Y$ to be exporter entry rates, exit rates, and entrant survival rates. ${ }^{26}$ Equation (3) includes exporting country-product-destination country fixed effects, $I_{c, k, d}$, as well as exporting country-year and destination country-year fixed effects as equation (2). The variable $X$ is the log of total annual exports

26 The entry rate is defined as the number of entrants in year $t$ relative to the total number of exporters in the same year. The exit rate in year $t$ is defined as the number of firms that exported in year $t-1$ but did not export in year $t$ relative to the total number of exporters in year $t$ - 1 . The entrant survival rate in year $t$ is defined as the number of entrants in year $t-1$ that survive onto year $t$ relative to the number of entrants in year $t-1$. 
by exporting country-product. Given the fixed effects $I_{c, k, d}$ included, the coefficient $\beta_{2}$ is identified based on within exporting country-product-destination country changes in numbers of exporters, entrants, or exiters or entry, exit, and entrant survival rates as pesticide standards change over time in the destination relative to the exporting country.

\section{Main Results}

\section{Effects of Standards on the Number of Exporters, Entrants, and Exiters}

Table 1 presents the results from estimating equation (3) by OLS for the number of exporters, entrants, and exiters in columns (1)-(3) and for entry, exit, and entrant survival rates in columns (4)-(6). ${ }^{27}$ Column (1) shows an increase in the stringency of destination country standards relative to exporting country standards negatively affects the number of firms participating in exports. The number of entrants and entry and entrant survival rates of exporters also are significantly lower when destination country standards are relatively more stringent, in columns (2), (4), and (6). In contrast, significantly higher numbers and rate of firms exit product-destination markets with more strict standards relative to their own country's standards in columns (3) and (5). These aggregate results suggest that differences in the relative stringency of pesticide standards in the destination market can act as a barrier to enter new markets and may encourage exit from existing markets.

Table 1. Effects of Standards on Numbers of Exporters, Entrants, and Exiters, and on Rates of Entry, Exit and Entrant Survival

\begin{tabular}{|c|c|c|c|c|c|c|}
\hline & \multicolumn{6}{|c|}{ Dependent Variable: } \\
\hline & $\begin{array}{c}\text { Number of } \\
\text { Exporters }_{c, k, d, t}\end{array}$ & $\begin{array}{l}\text { Number of } \\
\text { Entrants }_{c, k, d, t}\end{array}$ & $\begin{array}{l}\text { Number of } \\
\text { Exiters }_{\mathrm{c}, \mathrm{k}, \mathrm{d}, \mathrm{t}}\end{array}$ & $\begin{array}{c}\text { Exporter Entry } \\
\text { Rate }_{\mathrm{c}, \mathrm{k}, \mathrm{d}, \mathrm{t}}\end{array}$ & $\begin{array}{c}\text { Exporter Exit } \\
\text { Rate }_{\mathrm{c}, \mathrm{k}, \mathrm{d}, \mathrm{t}}\end{array}$ & $\begin{array}{c}\text { Entrant Survival } \\
\text { Rate }_{c, k, d, t}\end{array}$ \\
\hline & $(1)$ & $(2)$ & (3) & (4) & $(5)$ & (6) \\
\hline Rel_standards $\mathrm{c}_{\mathrm{c}, \mathrm{k}, \mathrm{d}, \mathrm{t}-1}$ & $\begin{array}{l}-0.095 \\
{[0.028]^{* * *}}\end{array}$ & $\begin{array}{l}-0.057 \\
{[0.021]^{* * *}}\end{array}$ & $\begin{array}{c}0.071 \\
{[0.023] * * *}\end{array}$ & $\begin{array}{c}-0.006 \\
{[0.008]^{*}}\end{array}$ & $\begin{array}{l}0.020 \\
{[0.008]^{* * *}}\end{array}$ & $\begin{array}{l}-0.027 \\
{[0.013]^{* *}}\end{array}$ \\
\hline $\operatorname{Tariff}_{c, k, d, t}$ & $\begin{array}{l}-0.012 \\
{[0.003]^{* * *}}\end{array}$ & $\begin{array}{l}-0.008 \\
{[0.003]^{* * *}}\end{array}$ & $\begin{array}{c}-0.001 \\
{[0.002]}\end{array}$ & $\begin{array}{c}0.000 \\
{[0.000]}\end{array}$ & $\begin{array}{c}0.000 \\
{[0.000]}\end{array}$ & $\begin{array}{c}-0.000 \\
{[0.001]}\end{array}$ \\
\hline Total Exports $\mathrm{c}_{\mathrm{c}, \mathrm{k}, \mathrm{t}}$ & $\begin{array}{l}0.125 \\
{[0.005]^{* * *}}\end{array}$ & $\begin{array}{c}0.076 \\
{[0.003]^{* * *}}\end{array}$ & $\begin{array}{c}0.001 \\
{[0.002]}\end{array}$ & $\begin{array}{l}-0.006 \\
{[0.002] * * *}\end{array}$ & $\begin{array}{l}-0.013 \\
{[0.001]^{* * *}}\end{array}$ & $\begin{array}{l}0.025 \\
{[0.001] * * *}\end{array}$ \\
\hline Observations & 168,368 & 168,368 & 168,368 & 68,349 & 69,572 & 43,214 \\
\hline R-squared & 0.942 & 0.783 & 0.632 & 0.536 & 0.607 & 0.454 \\
\hline
\end{tabular}

Source: Authors' analysis based on data from the Exporter Dynamics Database and from the Homologa.

Notes: Robust standard errors in brackets. $* * * *$, and * indicate significance at 1 percent, 5 percent, and 10 percent confidence levels, respectively. All regressions are estimated using OLS and include exporting country-product-destination country fixed effects, exporting country-year fixed effects, and destination country-year fixed effects.

\section{Effects of Standards on Firms' Export Decisions}

Table 2 presents our main baseline results from estimating equation (2). Inference is based on HuberWhite standard errors robust to heteroskedasticity clustered by exporting country-product-destination

27 Poisson estimation, which accounts for the count nature of the number of exporters, entrants, and exiters would be more appropriate but is impossible to implement with the large number of exporting country-year and destination country-year fixed effects included in equation (3). In unreported results, we used Poisson estimation for the number of exporters, entrants, and exiters including exporting country and destination country GDP per capita (using data from the World Development Indicators [WDI] database) as an alternative to the fixed effects. The results were qualitatively similar to those in table 1 and are available from the authors upon request. 
Table 2. Effects of Standards on Firms' Export Decisions at Extensive and Intensive Margins

\begin{tabular}{|c|c|c|c|c|c|c|}
\hline & \multicolumn{3}{|c|}{ Extensive Margin of Firm Exports } & \multicolumn{3}{|c|}{ Intensive Margin of Firm Exports } \\
\hline & \multicolumn{6}{|c|}{ Dependent Variable: } \\
\hline & $\begin{array}{l}\text { Export Participation } \\
\text { Dummy }_{c, i, k, d, t} \\
\text { (1) }\end{array}$ & $\begin{array}{l}\text { Export Entry } \\
\text { Dummy }_{c, \mathrm{i}, \mathrm{k}, \mathrm{d}, \mathrm{t}} \\
\text { (2) }\end{array}$ & $\begin{array}{c}\text { Export Exit } \\
\text { Dummy }_{c, i, k, d, t} \\
\text { (3) }\end{array}$ & $\begin{array}{c}\text { Export } \\
\text { Value }_{c, i, k, d, t} \\
(4)\end{array}$ & $\begin{array}{c}\text { Export } \\
\text { Quantity }_{c, i, k, d, t} \\
(5)\end{array}$ & $\begin{array}{c}\text { Export Unit } \\
\text { Price }_{\mathrm{c}, \mathrm{i}, \mathrm{k}, \mathrm{d}, \mathrm{t}} \\
(6)\end{array}$ \\
\hline Rel_standards $s_{\mathrm{c}, \mathrm{k}, \mathrm{d}, \mathrm{t}-1}$ & $\begin{array}{l}-0.015 \\
{[0.006] * * *}\end{array}$ & $\begin{array}{l}-0.015 \\
{[0.006]^{* *}}\end{array}$ & $\begin{array}{l}0.023 \\
{[0.010]^{* *}}\end{array}$ & $\begin{array}{c}-0.003 \\
{[0.035]}\end{array}$ & $\begin{array}{c}-0.014 \\
{[0.037]}\end{array}$ & $\begin{array}{c}0.011 \\
{[0.017]}\end{array}$ \\
\hline $\operatorname{Tariff}_{\mathrm{c}, \mathrm{k}, \mathrm{d}, \mathrm{t}}$ & $\begin{array}{l}-0.013 \\
{[0.002]^{* * *}}\end{array}$ & $\begin{array}{l}-0.010 \\
{[0.003] * * *}\end{array}$ & $\begin{array}{l}0.012 \\
{[0.004]^{* * *}}\end{array}$ & $\begin{array}{l}-0.040 \\
{[0.019] * *}\end{array}$ & $\begin{array}{l}-0.037 \\
{[0.018]^{* *}}\end{array}$ & $\begin{array}{c}-0.003 \\
{[0.007]}\end{array}$ \\
\hline Total Exports ${ }_{c, k, t}$ & $\begin{array}{l}0.042 \\
{[0.001] * * *}\end{array}$ & $\begin{array}{l}0.040 \\
{[0.001]^{* * *}}\end{array}$ & $\begin{array}{l}-0.059 \\
{[0.003] * * *}\end{array}$ & $\begin{array}{c}0.356 \\
{[0.020] * *}\end{array}$ & $\begin{array}{l}0.314 \\
{[0.020]^{* * *}}\end{array}$ & $\begin{array}{l}0.042 \\
{[0.007] * * *}\end{array}$ \\
\hline Estimation Method & $\begin{array}{c}\text { Linear Probability } \\
\text { Model }\end{array}$ & $\begin{array}{c}\text { Linear Probability } \\
\text { Model }\end{array}$ & $\begin{array}{c}\text { Linear Probability } \\
\text { Model }\end{array}$ & OLS & OLS & OLS \\
\hline Observations & $1,112,934$ & 753,324 & 219,861 & 147,394 & 147,394 & 147,394 \\
\hline R-squared & 0.406 & 0.253 & 0.486 & 0.922 & 0.939 & 0.934 \\
\hline
\end{tabular}

Source: Authors' analysis based on data from the Exporter Dynamics Database and from the Homologa.

Notes: Robust standard errors in brackets, clustered at the exporting country-product-destination country level. ***, **, and * indicate significance at 1 percent, 5 percent, and 10 percent confidence levels, respectively. The regressions in columns (1)-(3) are estimated using a linear probability model and those in columns (4)-(6) are estimated by OLS and all include exporting country-product-destination country fixed effects, exporting country-year fixed effects, and destination country-year fixed effects.

country since the specifications explain firms' export decisions with our standards index measured at that more aggregate level (Moulton 1990). For export participation, entry, and exit regressions, a linear probability model is used since probit models cannot be estimated with the panel fixed effects considered. ${ }^{28}$ The use of linear probability models for export participation-type decisions follows the study by Bernard and Jensen (2004) but has the shortcoming that the predicted probabilities may not be meaningful since they can lie outside of the $[0,1]$ interval; however, it is not a limitation to the qualitative predictions from the regressions which are the focus here. ${ }^{29}$ For intensive margin regressions OLS estimation is used.

The first three columns of table 2 show the estimated effects of pesticide standards on firms' extensive margin of trade. The negative and significant coefficient on Rel_standards in column (1) shows that firms are less likely to export a given product to destination countries as their standards become relatively more stringent than the firms' own country's standards. Similarly, a firm's probability to enter a new product-destination market decreases significantly when the destination's standards are relatively more stringent than those applied at home, as seen in column (2). Column (3) shows that, as standards in the destination country become more stringent relative to the exporting country, the likelihood that exporters stop exporting to that product-destination market increases significantly.

The last three columns of table 2 present the estimated effects of pesticide standards on firms' intensive margin of trade, which should be interpreted as the effect on firms' exports, conditional on there being positive exports. The estimates show that an increase in the stringency of standards imposed by the destination country relative to the exporting country leads to lower firm export values, quantities, and unit prices; however, the effects are not statistically significant. While we expected to find relatively more stringent standards in the destination country resulting in the import of higher quality products

28 Given the very large number of fixed effects in our specification, all our estimates in tables 4-10 are obtained using the reghdfe STATA command drawing on Correia (2015).

29 It is impossible to use a conditional fixed effects logit model for the extensive margin regressions (as in the working paper Fernandes et al. 2015), since those specifications do not converge when exporting country-year and destinationcountry-year fixed effects are included. 
commanding a unit price premia, on the contrary we find a negative (although insignificant) effect. The lack of a significant effect of relative standards on firm-product-destination export unit prices suggests that, unless cost pass-through onto prices is zero, compliance with relatively more stringent MRL standards imposes mostly (or only) fixed costs. Similarly, Ferro et al. (2015) find that the effect of standards on trade occurs mostly through the extensive margin rather than the intensive margin.

Incidentally, note that higher destination country tariffs have a significant negative effect on firms' export participation, entry, export value, and quantity and a significant positive effect on exit in table 2, as expected. The two types of trade policy measures—-tariffs and NTMs-have qualitatively similar impacts; however, tariffs significantly impact the intensive margin of trade whereas NTMs do not. ${ }^{30}$ A country's export capacity in a given product, measured by its annual total exports of that product, encourages firm exports at extensive and intensive margins.

We conducted several robustness checks to our main results in table 2 clustering the standard errors at the exporting country-firm level, re-estimating columns (1)-(3) for the sample of countries with quantity data, column (6) for a sample where unit prices that might be considered as outliers are dropped, and all columns using alternative sets of fixed effects as in Fontagné et al. (2015). The results are qualitatively maintained, as described in supplementary online appendix S4. To explore further the lack of significance of the relative standards index on export unit prices, we consider a different possibility, which is that the positioning of a firm in terms of quality, proxied by those export unit prices, plays a role in mediating the effects of the relative stringency of standards on firms' export entry and exit decisions. Estimates from a variant of equation (2) where the measure Rel_standards enters by itself but also interacted with a measure of the initial quality of the firm's product (given by the average of the export unit prices for the firm-product across all destinations in its first year in the sample) show that, for higher-quality firms, export entry is significantly less hampered by an increase in the relative stringency of standards in a destination country while export exit is less likely as a result of that increase (although not significantly so). The rationale for these findings is that higher-quality firms have a smaller adjustment to make in order to comply with the relatively more stringent foreign standards.

Overall, our evidence suggests that complying with relatively more restrictive foreign standards is costly for exporting firms. Higher relative stringency of standards in the destination market compared to the home market is associated with fewer firms exporting to that market and more firms exiting that market. There is no evidence of standards affecting the value, quantity, or price of exports. In the context of recent trade models with heterogeneous firms, an increase in the relative cost of exporting increases the minimum productivity threshold for firms to profitably export which affects the extensive margin of trade but not necessarily the intensive margin, as our results suggest.

\section{Heterogeneity in the Effects of Standards on Exporter Entry}

In this section, we explore the heterogeneity across firms that may lie behind the effects of product standards on firms' export entry decisions, focusing on the role of firm size and of networks. As discussed in section 4 , the relative stringency of standards in the destination country compared to the exporting country may affect firms' export entry decisions differently depending on firm size (a proxy for productivity), which determines the firm's ability to overcome additional costs required to export. Relatively more stringent destination standards could have a more detrimental impact on entry by small exporters. Additionally, standards could affect firms entering a new product-destination market differently than firms

30 Tariffs and our standards index have a statistically significant negative correlation of -0.04 obtained as the coefficient from a regression of our standards index on tariffs, controlling for exporting country-destination country, exporting country-product, and destination country-product fixed effects. This correlation suggests a degree of substitution across the two trade policy measures and confirms the importance of including tariffs as a control in specifications that estimate the impact of standards on firms' export decisions. 
entering one of their existing destination markets with a new product, or firms entering a new destination with a product they already export elsewhere. Networks (i.e., the presence of other firms from the same exporting country in a destination) may also play a role in alleviating the negative impact of relatively more stringent standards on export entry. A first network effect may occur as firms receive informationparticularly on standards-about potential new product-destination markets through firms already selling in those markets. ${ }^{31}$ A second network effect may occur when foreign buyers or distribution networks in a destination country attempt to expand imports to levels that previous exporters alone are unable to meet, hence new firms are approached to export to that destination. A third network effect of incumbent exporters on potential entrants may be through the availability of inputs in the home market such as replacement pesticides for banned ones or human capital with know-how to implement new production techniques to comply with foreign standards.

The results from estimating several variants of equation (2) where firm size and the measure Rel_standards enter by themselves but also through an interaction term are displayed in table 3. We consider various types of entry decisions in year $t$ for existing exporters (i.e., already exporting in year $t-1$ ): the decisions to enter into new products, new destinations, and/or new product-destinations. ${ }^{32}$ The focus on existing exporters is necessary as our measures of firm size are based on the one-year lag of firm agricultural export values in order to allow past performance to affect current firm export decisions and mitigate endogeneity concerns. Columns (1) and (4) measure size by the firm's total agricultural exports to all destinations (including those for which MRL data is not available and are not in our sample) Agro_exports $s_{c, i, t-1}$, thus estimating the effect of standards on entry of any type, be it of new products (in existing destinations), into new destinations (with existing products), or into new product-destinations. ${ }^{33}$ Column (2) measures size by the firm's agricultural exports to destination country $d$, Agro_exports_dest cr,i,,$t-1_{\text {, }}$, thus estimating the effect of standards on entry of new products in existing destinations. ${ }^{34}$ Column (3) measures size by the firm's exports of product $k$ to all destinations, Exports_product $t_{c, i, k, t-1}$, thus estimating the effects of standards on entry into new destinations with an existing product. ${ }^{35}$

An increase in the relative stringency of standards in the destination country compared to the exporting country reduces the likelihood of a firm engaging in any type of entry (column [1]), of a firm diversifying destinations for its existing products (column [3]) or of a firm exporting a new product to a new destination (column [4]). The coefficient on Rel_standards is positive but not statistically significant in column (2), suggesting that, for firms already exporting other products to a given destination, their decision to introduce new products to that destination is not affected by the stringency of products standards. A potential rationale is that the information asymmetries are reduced once the exporting firm has the know-how of how to operate and sell in a specific destination. All else equal, larger firms are significantly

31 Cadot et al. (2013) show that export market survival for African firms rises with the number of firms from the own country exporting the same product to the same destination, a key channel for the effects being the sharing of information among exporters already established in a market.

32 In all columns of table 3, the dependent variable is the same, but the specific type of entry decision and sample of entrants differ across columns depending on the measure of firm size used. The entirely new exporters in year $t$ (that did not export any product to any destination in year $t$-1) are excluded from the analysis as their size cannot be measured, thus the number of observations in table 3 is substantially smaller than that in column (2) of table 2 where they were included.

33 All measures of firm size enter the regressions in logarithms. Total agricultural exports cover exports in HS chapters 06-24 (except chapters 15-16). In column (4), only firms exporting to a new product-destination market are kept in the sample (i.e., firms only introducing a new product to an existing destination, or firms entering into a new market with an already existing product are dropped from the sample).

34 Firms which do not export agricultural products other than $k$ to destination $d$ in year $t$ - 1 are dropped from the estimating sample.

35 Firms that do not export product $k$ in year $t$ - 1 are dropped from the estimating sample. 
Table 3. Effects of Standards on Firms' Export Entry: Role of Firm Size and Network Effects

\begin{tabular}{|c|c|c|c|c|c|c|}
\hline & \multicolumn{6}{|c|}{ Dependent Variable: Export Entry Dummy ${ }_{\mathrm{c}, \mathrm{i}, \mathrm{k}, \mathrm{d}, \mathrm{t}, \mathrm{t}}$} \\
\hline & (1) & $(2)$ & (3) & (4) & (5) & (6) \\
\hline Rel_standards $\mathrm{c}_{\mathrm{c}, \mathrm{k}, \mathrm{d}, \mathrm{t}-1}$ & $\begin{array}{l}-0.071 \\
{[0.017]^{* * *}}\end{array}$ & $\begin{array}{c}0.010 \\
{[0.023]}\end{array}$ & $\begin{array}{l}-0.139 \\
{[0.024] * * *}\end{array}$ & $\begin{array}{l}-0.103 \\
{[0.037] * * *}\end{array}$ & $\begin{array}{l}-0.043 \\
{[0.027]^{* *}}\end{array}$ & $\begin{array}{l}-0.086 \\
{[0.018]^{* * *}}\end{array}$ \\
\hline Agro_exports $\mathrm{c}, \mathrm{i}, \mathrm{t}-1_{1}$ & $\begin{array}{l}0.044 \\
{[0.001]^{* * *}}\end{array}$ & & & $\begin{array}{l}0.021 \\
{[0.002]^{* * *}}\end{array}$ & $\begin{array}{l}0.044 \\
{[0.001]^{* * *}}\end{array}$ & $\begin{array}{l}0.044 \\
{[0.001]^{* * *}}\end{array}$ \\
\hline Rel_standards $\mathrm{c}_{\mathrm{c}, \mathrm{k}, \mathrm{d}, \mathrm{t}-1}$ X Agro_exports $\mathrm{c}_{\mathrm{c}, \mathrm{i}, \mathrm{t}-1}$ & $\begin{array}{l}0.005 \\
{[0.001]^{* * *}}\end{array}$ & & & $\begin{array}{c}0.005 \\
{[0.003]^{*}}\end{array}$ & $\begin{array}{l}0.005 \\
{[0.001]^{* * *}}\end{array}$ & $\begin{array}{l}0.005 \\
{[0.001]^{* * *}}\end{array}$ \\
\hline Agro_exports_dest $\mathrm{c}_{\mathrm{c}, \mathrm{i}, \mathrm{d}, \mathrm{t}-1}$ & & $\begin{array}{l}0.033 \\
{[0.001]^{* * *}}\end{array}$ & & & & \\
\hline Rel_standards $_{\mathrm{c}, \mathrm{k}, \mathrm{d}, \mathrm{t}-1}$ X Agro_exports_dest $\mathrm{c}, \mathrm{i}, \mathrm{d}, \mathrm{t}, \mathrm{1}_{1}$ & & $\begin{array}{c}-0.001 \\
{[0.002]}\end{array}$ & & & & \\
\hline Exports_product $_{\mathrm{c}, \mathrm{i}, \mathrm{k}, \mathrm{t}-1}$ & & & $\begin{array}{l}0.037 \\
{[0.001]^{* * *}}\end{array}$ & & & \\
\hline Rel_standards $_{\mathrm{c}, \mathrm{k}, \mathrm{d}, \mathrm{t}-1}$ X Exports_product $\mathrm{c}_{\mathrm{c}, \mathrm{i}, \mathrm{k}, \mathrm{t}-1}$ & & & $\begin{array}{l}0.012 \\
{[0.002]^{* * *}}\end{array}$ & & & \\
\hline Number_agro_firms $\mathrm{c}_{\mathrm{c}, \mathrm{d}, \mathrm{t}-1}$ & & & & & $\begin{array}{c}0.084 \\
{[0.006]^{* * *}}\end{array}$ & \\
\hline Rel_standards $_{\mathrm{c}, \mathrm{k}, \mathrm{d}, \mathrm{t}-1} \mathrm{X}$ Number_agro_firms $\mathrm{c}_{\mathrm{c}, \mathrm{d}, \mathrm{t}-1}$ & & & & & $\begin{array}{c}-0.006 \\
{[0.005]^{*}}\end{array}$ & \\
\hline Number_product_firms $\mathrm{c,d}, \mathrm{k}, \mathrm{t}-1$ & & & & & & $\begin{array}{l}0.062 \\
{[0.004]^{* * *}}\end{array}$ \\
\hline Rel_standards $_{\mathrm{c}, \mathrm{k}, \mathrm{d}, \mathrm{t}-1} \mathrm{X}$ Number_product_firms $\mathrm{c, \textrm {d } , \mathrm { k } , \mathrm { t } - 1}$ & & & & & & $\begin{array}{l}0.013 \\
{[0.004]^{* * * *}}\end{array}$ \\
\hline $\operatorname{Tariff}_{\mathrm{c}, \mathrm{k}, \mathrm{d}, \mathrm{t}}$ & $\begin{array}{l}-0.021 \\
{[0.003]^{* * *}}\end{array}$ & $\begin{array}{l}-0.022 \\
{[0.005]^{* * *}}\end{array}$ & $\begin{array}{l}-0.033 \\
{[0.005]^{* * *}}\end{array}$ & $\begin{array}{l}-0.016 \\
{[0.006]^{* * *}}\end{array}$ & $\begin{array}{l}-0.020 \\
{[0.003] * * *}\end{array}$ & $\begin{array}{l}-0.020 \\
{[0.003]^{* * * *}}\end{array}$ \\
\hline Total Exports ${ }_{\mathrm{c}, \mathrm{k}, \mathrm{t}}$ & $\begin{array}{l}0.039 \\
{[0.001]^{* * *}}\end{array}$ & $\begin{array}{l}0.037 \\
{[0.002] * * *}\end{array}$ & $\begin{array}{c}0.041 \\
{[0.002] * * *}\end{array}$ & $\begin{array}{c}0.034 \\
{[0.003] * * *}\end{array}$ & $\begin{array}{c}0.039 \\
{[0.001]^{* * *}}\end{array}$ & $\begin{array}{l}0.038 \\
{[0.001]^{* * * *}}\end{array}$ \\
\hline Observations & 359,726 & 165,023 & 164,278 & 41,550 & 359,726 & 359,726 \\
\hline R-squared & 0.274 & 0.304 & 0.295 & 0.388 & 0.275 & 0.276 \\
\hline
\end{tabular}

Source: Authors' analysis based on data from the Exporter Dynamics Database and from the Homologa.

Notes: Robust standard errors in brackets, clustered at the exporting country-product-destination country level. ***, $*$, and $*$ indicate significance at 1 percent, 5 percent, and 10 percent confidence levels, respectively. All regressions are estimated using a linear probability model and include exporting country-product-destination country fixed effects, exporting country-year fixed effects, and destination country-year fixed effects.

more likely to engage in the four types of export entry. The positive and significant interaction between Rel_standards and Agro_exports in columns (1) and (4) indicates that larger exporters are less negatively impacted by the relative stringency of standards in their market entry decisions. The interaction between Rel_standards and Exports_product in column (3) indicates that the negative effect of the relative stringency of standards on the likelihood of entering new destinations is mitigated for firms that are already large exporters of a product. The interaction between Rel_standards and Agro_exports_dest in column (2) is statistically insignificant.

All in all, we conclude that the size of the firm is an important direct mechanism through which the relative stringency of standards affects its decision to export to a new market. The findings are consistent with the evidence that larger exporting firms are more productive and with trade models' predictions that such firms are better able to absorb additional fixed and variable trade costs (here related to compliance with foreign standards). For smaller firms, the potential advantage of already complying with the standards for different products in a given destination country does not help them overcome the difficulties of complying with standards for a new product in that destination country. 
The regressions in columns (5)-(6) of table 3 explore networks as further channels through which firms might be able to reduce information asymmetries about destination market standards while also controlling for firm size. The proxy for the presence of networks is the one-year lag of: the number of firms from the same country as firm $i$ that export (any) agricultural products to each destination in year $t$-1, Number_agro_firms $s_{c, d, t-1}$ in column (5) and the number of firms from the same country exporting the same product $k$ to the same destination $d$ as firm $i$ in year $t-1$, Number_prod_firms $s_{c, k, d, t-1}$ in column (6).

The estimates show that firms are significantly more likely to enter into a new destination where more firms are already selling any agricultural product or where more firms are already selling the same product. The interaction between Rel_standards and Number_agro_firms in column (5) suggests that more stringent standards in a destination country relative to the exporting country affects even more negatively firm entry when a larger number of firms from the same country are already serving that destination with any agricultural products. This finding may signal a misinformation effect when other exporting firms are selling in the destination agricultural products that are not necessarily similar to the firm's products. The interaction between Rel_standards and Number_prod_firms in column (6) indicates that, when more firms from the same country already sell a product to a destination, a new firm's entry into that product-destination is less hampered by the higher relative stringency of destination standards.

Overall, these results provide some evidence of positive effects from networks for firms' decisions to start exporting to a new destination, as such networks likely help them overcome the regulatory impediments imposed by restrictive standards, but only when firms export the same product.

\section{Heterogeneity in the Effects of Standards on Exporter Exit}

In this section, we explore whether an increase in the relative stringency of standards impacts differentially firms' decisions to stop exporting to destinations where they previously sold agricultural products depending on firm size, the product's or the destination's importance in firm total exports. A firm deriving most of its export revenue from a single product could be more likely to incur in the costs required to comply with changes in standards so as to sustain its main source of revenue. In contrast, a firm selling multiple products might stop exporting a product that is not important for its overall export portfolio if it is costly to comply with changes in standards due to the small scale of the exports. A similar reasoning applies to the importance of the destination.

Table 4 shows the results from estimating several variants of equation (2) where the measure Rel_standards enters by itself but also interacted with firm size (Agro_exports coi,t-1 $_{\text {) }}$ ) as well as with the share in the firm's total agricultural exports of a product's exports, Product_share ${ }_{c, i, k, t-1}$, or of a destination's exports, Destination_share ${ }_{c, i, d, t-1}$. Firm size and the product or destination shares also enter by themselves. By definition the exit regressions focus on the decision to stop exporting to a product-destination market for existing exporters.

Firms are more likely to stop exporting a product to a destination whose stringency of standards increases relative to the home standards in column (1) (as in table 2). Larger firms are significantly less likely to exit their export markets, with all else equal. The interaction between Rel_standards and Agro_exports shows that larger firms are significantly less likely to exit a product-destination market due to the relative stringency of that destination's standards.

The estimates in columns (2) and (3) show that, all else equal, the more important is a product or a destination to a firm, the less likely the firm is to stop exporting that product or to that destination, respectively. The interaction between Rel_standards and Product_share suggests a less severe exit-inducing effect of relatively more stringent standards for products that account for a larger share of firms' export portfolios. Conversely, the interaction between Rel_standards and Destination_share suggest a more severe exit-inducing effect of relatively more stringent standards for destinations that account for a larger share 
Table 4. Effects of Standards on Firms' Export Exit: Role of Firm Size and Network Effects

\begin{tabular}{|c|c|c|c|c|}
\hline & \multicolumn{4}{|c|}{ Dependent Variable: Export Exit Dummy ${ }_{\mathrm{c}, \mathrm{i}, \mathrm{k}, \mathrm{d}, \mathrm{t}}$} \\
\hline & (1) & $(2)$ & (3) & (4) \\
\hline Rel_standards $\mathrm{c}_{\mathrm{c}, \mathrm{k}, \mathrm{d}, \mathrm{t}-1}$ & $\begin{array}{l}0.166 \\
{[0.039] * * *}\end{array}$ & $\begin{array}{l}0.205 \\
{[0.039] * * *}\end{array}$ & $\begin{array}{l}0.110 \\
{[0.047]^{* *}}\end{array}$ & $\begin{array}{l}0.145 \\
{[0.047] * * *}\end{array}$ \\
\hline Agro_exports ${ }_{\mathrm{c}, \mathrm{i}, \mathrm{t}-1}$ & $\begin{array}{l}-0.075 \\
{[0.002] * * *}\end{array}$ & $\begin{array}{l}-0.079 \\
{[0.002] * * *}\end{array}$ & $\begin{array}{l}-0.080 \\
{[0.002]^{* * *}}\end{array}$ & $\begin{array}{l}-0.083 \\
{[0.002] * * *}\end{array}$ \\
\hline Rel_standards $\mathrm{c}_{\mathrm{c}, \mathrm{k}, \mathrm{d}, \mathrm{t}-1}$ X Agro_exports $\mathrm{c}_{\mathrm{c}, \mathrm{i}, \mathrm{t}-1}$ & $\begin{array}{l}-0.011 \\
{[0.003] * * *}\end{array}$ & $\begin{array}{l}-0.012 \\
{[0.003] * * *}\end{array}$ & $\begin{array}{l}-0.008 \\
{[0.003]^{* * *}}\end{array}$ & $\begin{array}{l}-0.009 \\
{[0.003]^{* * *}}\end{array}$ \\
\hline Product_share $\mathrm{c}_{\mathrm{c}, \mathrm{i}, \mathrm{k}, \mathrm{t}-1}$ & & $\begin{array}{l}-0.117 \\
{[0.011] * * *}\end{array}$ & & $\begin{array}{l}-0.104 \\
{[0.011] * * *}\end{array}$ \\
\hline Rel_standards $_{\mathrm{c}, \mathrm{k}, \mathrm{d}, \mathrm{t}-1}$ X Product_share ${ }_{\mathrm{c}, \mathrm{i}, \mathrm{k}, \mathrm{t}-1}$ & & $\begin{array}{l}-0.049 \\
{[0.015] * * *}\end{array}$ & & $\begin{array}{l}-0.048 \\
{[0.015] * * *}\end{array}$ \\
\hline Destination_share $_{c, i, d, t-1}$ & & & $\begin{array}{l}-0.132 \\
{[0.009] * * *}\end{array}$ & $\begin{array}{l}-0.121 \\
{[0.009] * * *}\end{array}$ \\
\hline Rel_standards $\mathrm{c}_{\mathrm{c}, \mathrm{k}, \mathrm{d}, \mathrm{t}-1}$ X Destination_share $\mathrm{c}_{\mathrm{c}, \mathrm{i}, \mathrm{d}, \mathrm{t}-1}$ & & & $\begin{array}{l}0.049 \\
{[0.016] * * *}\end{array}$ & $\begin{array}{c}0.052 \\
{[0.016] * * *}\end{array}$ \\
\hline $\operatorname{Tariff}_{\mathrm{c}, \mathrm{k}, \mathrm{d}, \mathrm{t}}$ & $\begin{array}{c}0.011 \\
{[0.004] * * *}\end{array}$ & $\begin{array}{l}0.012 \\
{[0.004] * * *}\end{array}$ & $\begin{array}{c}0.011 \\
{[0.004]^{* * *}}\end{array}$ & $\begin{array}{l}0.012 \\
{[0.004]^{* * *}}\end{array}$ \\
\hline Total Exports $_{\mathrm{c}, \mathrm{k}, \mathrm{t}}$ & $\begin{array}{l}-0.058 \\
{[0.003] * * *}\end{array}$ & $\begin{array}{l}-0.058 \\
{[0.003] * *}\end{array}$ & $\begin{array}{l}-0.058 \\
{[0.003]^{* * *}}\end{array}$ & $\begin{array}{l}-0.058 \\
{[0.003] * *}\end{array}$ \\
\hline Observations & 219,861 & 219,861 & 219,861 & 219,861 \\
\hline R-squared & 0.496 & 0.496 & 0.497 & 0.497 \\
\hline
\end{tabular}

Source: Authors' analysis based on data from the Exporter Dynamics Database and from the Homologa.

Notes: Robust standard errors in brackets, clustered at the exporting country-product-destination country level. ${ }^{* * *}, *$, and $*$ indicate significance at 1 percent, 5 percent, and 10 percent confidence levels, respectively. All regressions are estimated using a linear probability model and include exporting country-product-destination country fixed effects, exporting country-year fixed effects, and destination country-year fixed effects.

of firms' export portfolios. The specification in column (4) which controls for firm size, product share, destination share, and the interaction between each of these variables, and the Rel_standards measure provides qualitatively similar results to those in columns (1)-(3).

Overall, these findings suggest that firm size plays an important role in mitigating the impact of the relative stringency of a destination's standards on a firm's decision to stop exporting to that productdestination market and that a firm might adapt to a destination's increase in the stringency of standards if the product represents an important share of its total exports.

\section{Heterogeneity in the Effects of Standards-Endogeneity and Alternative Indexes}

While we believe that our estimated impacts of the relative stringency of standards on firm export entry and exit and the mitigating role of firm size are insulated from omitted variables and reverse causality biases due to the rich set of fixed effects included and the use of the one-year lag of the standards index, we address any potential remaining endogeneity concerns following Fontagné et al. (2015), who propose to instrument the standards index with an average of the index across products in the same HS fourdigit category. The IV estimates presented in supplementary online appendix table $\$ 4.1$ confirm our main findings. We also address issues of measurement and variability in our standards index. First, we reestimate our specifications, including a standards index that relies on a different strategy to fill in missing MRL information, which is to replace it with the Codex MRL (if one exists) for the product-pesticide pair. The estimates presented in supplementary online appendix table S4.1 show that the specific strategy used to fill in missing MRL information does not affect the estimated effects of the relative stringency of destination standards on firms' export entry and exit decisions. Second, we re-estimate our specifications 
using the main standards index but restricting the sample to include only exporting countries which draft specific MRL regulations, addressing the fact that the excluded countries which use Codex as their own regulations reduce the effective variability in the standards index. The results are qualitatively maintained. Third, to distinguish across the sources of MRL differentials captured by our standards index discussed in section 2, we estimate new specifications including two separate measures of standards, one for the destination country and one for the exporting country, each defined relative to Codex, as described in supplementary online appendix S.4. Importantly, the estimates show that both the destination country's stringency of standards relative to Codex as well as the exporting country's stringency of standards relative to Codex matter, both impact negatively exporter entry and positively exporter exit, with those impacts being weaker for larger exporters.

\section{Conclusion}

This paper examines the importance of standards' regulations in influencing the ability of firms in developing countries to exploit export opportunities for agricultural and food products. Our findings show a significant effect of relatively more stringent destination country standards in depressing firms' exports at the extensive margin but no effect at the intensive margin. Our results are consistent with recent trade models which predict that only the most productive firms are able to overcome the fixed costs of exporting. Obtaining information on foreign standards and adjusting production processes to comply with those standards increase the fixed costs to reach foreign markets. This helps explain the stronger effect on smaller firms' entry and exit decisions of the relative stringency of destination country standards compared to exporting country standards.

Overall, our evidence suggests that the relative stringency of destination country pesticide standards compared to exporting country pesticide standards restricts market access for firms. But it is important to emphasize that this restriction in market access is not always the result of the more stringent standards of destination countries; rather, it often results from the looser standards of exporting countries that hurt their firms' capacity to export.

The international community has attempted to overcome the potentially trade-distortive effects of standards through the WTO SPS Agreement and other trade tools. This has included decades of discussion about the benefits of standard harmonization, use of international standards through international bodies such as Codex Alimentarius, and potential cost of domestic standards that deviate from international norms. Limited progress has been made, however, in these various efforts to mitigate the effect of discriminatory or duplicative national standards. More importantly, developing countries lack access to compliance resources, including scientific and technical expertise, information, and finance to exploit the opportunities offered in various trade agreements.

Looking ahead, it is important that new trade talks consider and address the channels through which NTMs affect trade. SPS standards, including pesticide MRLs, continue to be developed by national governments, and this heterogeneity is likely to remain in place since full global harmonization of such standards is impossible. Furthermore, the development of new and deeper trade agreements in which NTMs are included-which is the case for the TPP and TTIP-will greatly impact third-country firms in developing countries that may be unable to meet the new agreed-upon standards. Thus, for developing countries that seek to support its agricultural exporters in terms of their entry and survival in markets with more stringent SPS standards, our work suggests that governments need to optimize the regulatory framework and provide the proper infrastructure that would allow exporters to minimize the costs to meet foreign and local standards. Governments can do this, for example, by fostering the work of export promotion agencies in reducing asymmetries of information for potential exporters on foreign regulations, by facilitating access to the imports of inputs necessary to comply with foreign standards, and creating the testing facilities that are capable of checking compliance with foreign standards. 
Future research on the effects of NTMs on trade should expand the analysis to the manufacturing sector using measures that account not only for the number of standards but also for their stringency, as we have done in this paper with standards for agricultural products. In addition, while our study focuses on the impact of "de jure" regulations, the implementation of these regulations at ports and bordercrossing points may or may not be fully enforced by the destination country's authorities. Investigating those effects is left for future work.

\section{References}

Anders, S., and J. Caswell. 2009. "Standards as Barriers versus Standards as Catalyst: Assessing the Impact of HACCP Implementation on U.S. Seafood Imports." American Journal of Agricultural Economics 91 (2): 310-21.

Augier, P., O. Cadot, and M. Dovis. 2015. "NTM Harmonization, Profits, and Productivity: Firmlevel Evidence from Morocco.” Mimeo. University of Lausanne.

Arkolakis, C. 2010. "Market Penetration Costs and the New Consumers Margin in International Trade." Journal of Political Economy 118 (6): 1151-99.

Bernard, A., and B. Jensen. 2004. "Why Some Firms Export." Review of Economics and Statistics 86 (2): 561-9.

Bernard, A., S. Redding, and P. Schott. 2011. "Multi-Product Firms and Trade Liberalization." Quarterly Journal of Economics 126 (3): 1271-318.

Bils, M., and P. Klenow. 2001. "Quantifying Quality Growth.” American Economic Review 91 (4): 1006-30.

Broda, C., and J. Romalis. 2009. “The Welfare Implications of Rising Price Dispersion.” Mimeo. University of Chicago.

Cadot, O., and M. Malouche. 2012. Non-Tariff Measures-A Fresh look at Trade Policy's New Frontier. CEPR and World Bank.

Cadot, O., L. Iacovone, M. Pierola, and F. Rauch. 2013. "Success and Failure of African Exporters." Journal of Development Economics 101: 284-96.

Cato, J., W. Otwell, and A. Coze. 2004. "Nicaragua's Shrimp Subsector: Developing a Production Capacity and Export Market during Rapidly Changing Worldwide Safety and Quality Regulations.” Agriculture and Rural Development Discussion Papers No. 47844, World Bank, Washington D.C.

Cebeci, T., A. Fernandes, C. Freund, and M. Pierola. 2012. "Exporter Dynamics Database.” Policy Research Working Paper No. 6229, World Bank, Washington D.C.

Chaney, T. 2008. "Distorted Gravity: The Intensive and Extensive Margins of International Trade." American Economic Review 98 (4): 1707-21.

Chen, X., J. Wilson, and T. Otsuki. 2010. "Standards and Export Decisions: Firm-Level Evidence from Developing Countries." Journal of International Trade and Economic Development 17 (4): 501-23.

Correia, S. 2015. "Linear Models with High-Dimensional Fixed Effects: An Efficient and Feasible Estimator.” Mimeo. Duke University.

Czubala, W., B. Shepherd, and J. Wilson. 2009. "Help or Hindrance? The Impact of Harmonized Standards on African Exports.” Policy Research Working Paper No. 4400, World Bank, Washington D.C.

Disdier, A. C., L. Fontagné, and O. Cadot. 2015. "North-South Standards Harmonization and International Trade." World Bank Economic Review 29 (2): 327-52.

Disdier, A. C., L. Fontagné, and M. Mimouni. 2008. “The Impact of Regulations on Agricultural Trade: Evidence from the SPS and TBT Agreements." American Journal of Agricultural Economics 90 (2): 336-50.

Drogué, S., and F. DeMaria. 2012. "Pesticide Residue and Trade, the Apple of Discord?" Food Policy 37 (6): 641-9.

Fernandes, A., E. Ferro, and J. Wilson. 2015. "Product Standards and Firms' Export Decisions.” Policy Research Working Paper No. 7315, World Bank, Washington D.C.

Fernandes, A., C. Freund, and M. Pierola. 2016. "Exporter Behavior, Country Size and Stage of Development: Evidence from the Exporter Dynamics Database." Journal of Development Economics 119: 121-37.

Ferro, E., J. Wilson, and T. Otsuki. 2015. "The Effect of Product Standards on Agricultural Exports." Food Policy 50: 68-79.

Fontagné, L., G. Orefice, R. Piermartini, and N. Rocha. 2015. "Product Standards and Margins of Trade: Firm Level Evidence." Journal of International Economics 97 (1): 29-44.

Hallack, J. C. 2006. "Product Quality and the Direction of Trade." Journal of International Economics 68 (1): 238-65. 
Henson, S., A.M. Brouder, and W. Mitullah. 2000. "Food Safety Requirements and Food Exports from Developing Countries: The Case of Fish Exports from Kenya to the European Union." American Journal of Agricultural Economics 82 (5): 1159-69.

Koenig, P., F. Mayneris, and S. Poncet. 2010. “Local Export Spillovers in France.” European Economic Review 54 (4): $622-41$.

Koenig, P. 2009. “Agglomeration and the Export Decisions of French Firms.” Journal of Urban Economics 66 (3): 186-95.

Li, Y., and J. Beghin. 2012. "Protectionism Indices for Non-Tariff Measures: An Application to Maximum Residue Levels.” Iowa State Working Paper No. 12013.

Maskus, K., T. Otsuki, and J. Wilson. 2005. “The Cost of Compliance with Product Standards for Firms in Developing Countries: An Econometric Study.” Policy Research Working Paper No. 3590, World Bank, Washington D.C.

Maertens, M., and J. Swinnen. 2009. “Trade, Standards and Poverty: Evidence from Senegal.” World Development 37 (1): 161-78.

Mayneris, F., and S. Poncet. 2015. “Chinese Firms' Entry to Export Markets: The Role of Foreign Export Spillovers.” World Bank Economic Review 29 (1): 150-79.

Melitz, M. 2003. “The Impact of Trade on Intra-Industry Reallocations and Aggregate Industry Productivity.” Econometrica 71 (6): 1695-725.

Moulton, B. 1990. “An Illustration of a Pitfall in Estimating the Effects of Aggregate Variables on Micro Units." Review of Economics and Statistics 72 (2): 334-8.

Otsuki, T., J. Wilson, and M. Sewadeh. 2001a. "Saving Two in a Billion: Quantifying the Trade Effect of European Food Safety Standards on African Exports." Food Policy 26: 495-514.

Otsuki, T., J. Wilson, and M. Sewadeh. 2001b. "What Price Precaution? European Harmonization of Aflatoxin Regulations and African Groundnut Exports.” European Review of Agriculutural Economics 28 (2): $263-83$.

Reyes, J-D. 2011. "International Harmonization of Product Standards and Firm Heterogeneity in International Trade.” Policy Research Working Paper No. 5677, World Bank, Washington D.C.

Shepherd, B., and N. Wilson. 2013. "Product Standards and Developing Country Agricultural Exports: The Case of the European Union." Food Policy 42: 1-10.

Spearot, A. 2014. “Tariffs, Competition, and the Long of Firm Heterogeneity Models.” Mimeo. University of California, Santa Cruz.

Tran, N., N. Wilson, and S. Anders. 2011. "Standard Harmonization as Chasing Zero (Tolerance Limits): The Impact of Veterinary Drug Residue Standards on Crustacean Imports in the EU, Japan and North America.” American Journal of Agricultural Economics 94 (2): 496-502.

Wilson, J., T. Otsuki, and B. Majumdsar. 2003. "Balancing Food Safety and Risk: Do Drug Residue Limits Affect International Trade in Beef?" Journal of International Trade and Economic Development 12 (4): $377-402$.

Winchester, N., M. Rau, C. Goetz, B. Larue, T. Otsuki, K. Shutes, C. Wieck, H. Burnquist, M. Pinto de Souza, and R. de Faria. 2012. "The Impact of Regulatory Heterogeneity on Agri-Food Trade.” World Economy 35 (8): $973-93$.

Xiong, B., and J. Beghin. 2010. "Does European Aflatoxin Regulation Hurt Groundnut Exporters from Africa?" European Review of Agricultural Economics 39 (4): 589-609. 